\title{
Gut Histomorphometric And Blood Profile Of Broiler Chicks Fed Varied Levels Of Protein
}

\author{
${ }^{1}$ Shittu, M. D, ${ }^{2}$ Adejumo, D. O, ${ }^{3}$ Ademola, S. G, ${ }^{4}$ Alagbe, J.O \\ ${ }^{1}$ Dept.of Animal Production and Health, Ladoke Akintola University of Technology (LAUTECH) Ogbomoso, Nigeria. \\ ${ }^{2}$ Dept.of Animal Science, University of Ibadan, Ibadan. \\ ${ }^{3}$ Dept.of Animal Nutrition and Biotechnology, LAUTECH, Ogbomoso. \\ ${ }^{4}$ Department of Animal Nutrition \& Biochemistry, Sumitra Research Institute, Gujarat, India.
}

\begin{tabular}{lll}
\multicolumn{3}{l}{ Article Information } \\
Received $\quad:$ & 01 Oct 2020 \\
Revised $\quad:$ & 10 Oct 2020 \\
Accepted $\quad:$ & 19 Oct 2020 \\
Published & $:$ & 30 Oct 2020
\end{tabular}

Corresponding Author:

Shittu, M. D

Email: shittumdaniel@gmail.com

\begin{abstract}
Gut plays active role in screening what goes into the blood stream and blood is very important parameter to access for us to establish the health status of animal to any dietary variation, this will help the producer ability to guaranty the consumers' health. Therefore this research was designed to determine gut histomorphometry and blood profile of broiler starter fed varied levels of protein. Material and method is A total of 144 days-old-broiler chicks were used for the study. Broiler standard starter mash with varied protein percentages of 20, 23, and 26\%, respectively for treatments 1,2 and 3 were used. Data were analysed using ANOVA at $\alpha 0.05$. Results is Except crude protein and ash contents, others nutrient digestibilities were not affected by the dietary treatments. Birds fed lower crude protein had the lowest crude protein digestibility while birds fed standard diet $(23 \% \mathrm{CP})$ had the best and highest crude protein digestibility. White blood cell decrease with decrease dietary protein, this might have serious effect on the immunity level of the broilers. Also globulin increases while albumin decreases with increase in dietary protein levels. Serum total protein increases with increase in the dietary protein levels and diet with $26 \%$ CP recorded the highest value $(5.82 \mathrm{~g} / \mathrm{dL})$. Serum cholesterol values were significantly higher at lower protein level unlike serum protein whiledifferent gut parts response significantly different to dietary treatments. Conclusion is at early stage broiler growth, diet need to have higher CP to improve the immunity and health growth of gut.
\end{abstract}

Keywords: broiler, blood profile, globulin, histomorphometric.

\begin{abstract}
Copyright () 2020: Shittu, M. D, Adejumo, D. O, Ademola, S. G, Alagbe, J.O. This is an open access distribution, and reproduction in any medium, provided Access article distributed under the Creative Commons Attribution License the original work is properly cited License, which permits unrestricted use.
\end{abstract}

Citation: Shittu, M. D, Adejumo, D. O, Ademola, S. G, Alagbe, J.O. "Gut Histomorphometric And Blood Profile Of Broiler Chicks Fed Varied Levels Of Protein", Journal of Science, Computing and Engineering Research, 1(4), 106-111,SeptemberOctober 2020.

\section{INTRODUCTION}

Protein nutrition has a great economic importance, since protein is an expensive item in almost all feed rations. This may be particularly so in areas of the world known to be protein deficient, such as many tropical and subtropical areas (Poultry World, 2016). Wasting or supplying in excess of what the broiler need may cause a lot of economic loss, so no farmer will encourage such. According to Poultry World (2016) rationing of feed for protein should therefore be manipulated in such a way that optimal rather than maximum performance is achieved without too much feed expenditure on broiler production.Broilers according to Tom Kruchten, (2002) are chicken (Gallus domesticus) bred and raised specifically for meat production. Typical broilers have white feathers and yellow skin and most commercial broilers bred for meat reach slaughter weight between 5 and 6 weeks of age. According to Amber-Jean Nash, (2012), there are only two original breeds of broiler which are Cornish and white rocks. Given broilers access to a diet of high protein combined with artificial lightening conditions stimulate growth, thus the desired body weight is achieved and Poultry World (2016) established that protein is vital nutrient for poultry growth and development. Gut must also play a serious role before this expensive nutrient will be available to the broiler.

Digestion of feed to make the various nutrients available can only be achieved when the gut is sound and able to perform the digestive roles. Different part of the gut perform different digestive role that make the ingested feed to become readily available in the gut for microvilli to absorb into the blood stream. Blood is a vital circulatory fluid that circulates through heart, arteries, capillaries and veins; it is composed of cells suspended in a fluid intercellular substance (plasma) with the major function of maintaining homeostasis (Isaac et al., 2013). Haematological components, which consists of red blood cells, white blood cells or leucocytes, mean corpuscular haemoglobin and mean corpuscular haemoglobin concentration are valuable in monitoring feed toxicity especially with feed constituent that affect the blood as well as the health status of farm animals (Oyawoye and Ogunkunle., 2004). Red blood cells 
(erythrocytes) serve as a carrier of haemoglobin. It is the haemoglobin that reacts with oxygen carried in the blood to form oxyhaemoglobin which transport oxygen to the cells of the body during respiration (Chinekeet al., 2006). According to Isaac (2013) red blood cells is involved in the transport of oxygen and carbon dioxide in the body. Thus, a reduced red blood cell count implies a reduction in the level of oxygen that would be carried to the tissues as well as the level of carbon returned to the lungs (Soetanet al. 2013). Gut make the nutrient available to the blood and blood provides useful information on nutritional status and clinical investigation on the animal, hence, World Health Organization (WHO) recommend the use of blood parameters for medical and nutritional assessment (Egbunikeet al., 2009). Therefore, this research work was designed to determine the effect of different dietary protein levels on the gut histomorphometry, haematological and serum biochemistry of broiler chicks.

\section{MATERIAL AND METHODS}

The experiment was carried out at the Poultry Unit of the Teaching and Research Farm, LAUTECH, Ogbomosho, Oyo state, Nigeria, Ogbomoso is in the derived savannah zone of Nigeria.

\section{A. Pre-operational management}

Preparation before arrival of the birds include general cleaning of the pen which involved sweeping, washing, scrubbing, fumigation of the pen, removal of unused wood, repair and partitioning of damaged nets and also washing and disinfecting the feeder and watering trough, all these were done before the wood shavings was sourced for at Ogbomoso saw mill. Materials for brooding were made available while alternative provisions were put in place in case of electricity fluctuation.

\section{B. Animal Handling}

Total of one hundred and forty-four days old broiler chicks (Arbor acre strain) were used for the study and broiler starter mash containing 3000 Metabolisable energy $\mathrm{Kcal} / \mathrm{kg}$ with varied protein percentage of 20,23 , and $26 \%$, respectively for treatments 1,2 and 3, tagged Diet 1 , diets 2 and diet 3 , respectively, were fed to the broiler chicks (Table 1). The chicks were weighed and randomly allotted to the three dietary treatments in triplicate of 16 chicks each in a completely randomized design.

Table I. Composition of Starter Diets (g/100g DM)

\begin{tabular}{llll}
\hline Ingredients & Diet 1 & Diet 2 & Diet 3 \\
\hline Maize & 58.25 & 52.05 & 41.95 \\
Soybeans & 30.20 & 34.20 & 44.30 \\
Fish meal & 2.00 & 2.00 & 2.00 \\
Brewer's dried & 4.20 & 4.20 & 4.20 \\
grain & & & \\
Vegetable Oil & 3.00 & 3.00 & 3.00 \\
Di Calcium & 1.50 & 1.50 & 1.50 \\
\hline
\end{tabular}

\begin{tabular}{llll}
\hline Phosphate & & & \\
Oystershell & 1.25 & 1.25 & 1.25 \\
Salt & 0.25 & 0.25 & 0.25 \\
Methionine & 0.15 & 0.15 & 0.15 \\
Lysine & 0.15 & 1.15 & 1.15 \\
**Premix & 0.25 & 0.25 & 0.25 \\
Total & $\mathbf{1 0 0 . 0 0}$ & $\mathbf{1 0 0 . 0 0}$ & $\mathbf{1 0 0 . 0 0}$ \\
Crude protein & 20.02 & 23.05 & 26.00 \\
$\begin{array}{l}\text { (\%) } \\
\text { Metabolisable }\end{array}$ & 3164.45 & 3131.02 & 3056.88 \\
Energy & & & \\
(kcal/g) & & & \\
Crude fibre & 3.32 & 3.68 & 3.75 \\
$(\%)$ & & & \\
\hline
\end{tabular}

Diet 1: 20\%CP, Diet 2: 23\%CP, Diet 3: $26 \% \mathrm{CP}$, **Premix composition:

Premix composition (per $\mathrm{kg}$ of diet) Vit (Vitamin) $\mathrm{A}=1000 \mathrm{IU}$; Vitamin D3=2000 IU; Vit E=4000 mg; Vit K3=900 mg; Vit B1=500 mg; Vit B2=2200 mg; Vit B3=5500 mg; Vit B12=4 mg; pp=18000; Folic acid $=400$ $\mathrm{mg}$; Choline chloride $=150000 \mathrm{mg}$; Antioxidant BHT $=0.05 \%$; Iron $=1.80 \%$; Copper $=0.20 \%$; $\mathrm{Mn}=2.40 \%$; Cobalt $=0.04 \% ; \quad \mathrm{Zn}=2.80 \% ; \quad$ Iodine $=0.04 \%$; Selenium $=0.016 \% ; \mathrm{Ca}=12.8570 \%$ in $2.5 \mathrm{~kg}$.

\section{A. Digestibility trial}

At 28 days, four (4) birds were randomly selected per treatment and transferred to the metabolic cage for digestibility trial. The birds were acclimatized for three days, data on daily feed intake were collected. On the fourth day, the dropping of the birds were collected on aluminum foil paper and weighed at the same time using sensitive scale. The daily droppings from each treatment were dried, weighed before being grinded using manual grinder, and sub sample were taken for proximate composition

\section{B. Blood Analysis}

Blood samples were obtained from the jugular vein of two birds per replicate on the 28day into tubes containing EDTA (an anticoagulant) for haematology, while those for serum were without EDTA. The blood analysis was determined as reported by Shittu el al. (2017).

\section{Gut histomorphometric analysis}

The samples were handled as described (Onderci et al., 2008). The samples were placed in a10\% buffered neutral formaldehyde solution ( $\mathrm{pH} 7.2$ - 7.4) and were gradually dehydrated with increasing concentrations of ethyl alcohol $(50-100 \%)$. The dehydrated specimens were embedded in paraffin, sectioned at $5 \mu \mathrm{m}$ and stained with haematoxylin and eosin (Gracia et al., 2009). The sections were analyzed 
under a light microscope (Nikon Eclipse E200) and the height and width of the villus were measured using a computer assisted image analysis. A total of 15 intact well oriented cryptvillus units were selected randomly for each sample. The mean values attributed to individual bird were used in the statistical analysis. Villus height was measured from the tip of the villus to the crypt-villus junction, whereas crypt depth was defined as the depth of the invagination between adjacent villi ( $\mathrm{Hu}$ and Guo, 2006). The villus width was defined as the distance from the outside epithelial edge along a line passing through the vertical midpoint of the villus. Data analysis: Data generated were subjected to ANOVA using SPSS version 12 at $\alpha 0.05$.

\section{RESULTS AND DISCUSSION}

The digestibility of proximate constituents by broiler starter fed varied levels of protein is shown in Table II. Except crude protein and ash contents, others nutrient digestibilities were not affected by the dietary treatments. Birds fed lower crude protein had the lowest crude protein digestibility while birds fed standard diet $(23 \% \mathrm{CP})$ had the best and highest crude protein digestibility. Table 2 shows that broiler chick crude protein digestibility has to be met and adequate to avoid wastage and unavailable in the broiler diet. Lohakareet al. (2006) suggested that increase dietary crude protein might lead to possible increase in the endogenous nitrogen losses due to increase in dietary protein levels and this suggest that the intake was in excess of the animals capacity to utilize nitrogen efficiently. The result of this study contradicts the report of Youssef et al. (2017), who observed increase in the crude protein digestibility as the dietary crude protein decreases. This may be as a result of the class and age of the chickens. The fact was supported by Youssef et al. (2017) that different environmental, nutritional and hygienic conditions can affect the growth of broiler chickens.

Table III shows the haematological parameters of the broiler fed varied levels of protein at starter phase. White blood cell decrease with decrease dietary protein, this might have serious effect on the immunity level of the broilers.Birds on lower crude protein diet had the highest blood monocytes $(3.56 \%)$ level compare to other treatments. Also globulin increases while albumin decreases with increase in protein. Platelet activity processes were similar irrespective of the dietary protein level. Packed cell volume (PCV), MCV, MCH, Hb, monocytes of blood is a means of assessing clinical and nutritional health status of animals in feeding trial (Adeyemi et al.,2000). The protein requirements by animals depend on many factors such as species, breed, age, physiological status and environmental factors (Abdelrahman and Aljumaah, 2014). White blood cell decrease with decrease dietary protein, this might have serious effect on the immunity level of the broilers. This agrees with the report of Carlomagno et al. (1980) that protein deficiency inhibits antibodies production cells in response to T-dependent antigens. Huwaida et al. (2013) reported variation of different strain to different protein levels eg Cobb fed low protein had higher growth compare to Ross, Habbard etc. The authors reported variation in antibody titers as affected by strain, Ross fed high crude protein has higher antibodies titers.

Platelet activity processes were similar irrespective of the dietary protein level. This shows that $20 \%$ protein level still enable the normal activity of the thrombocytes of broiler at starter phase. Platelets help to stop the bleeding at any site of endothelium interruption, this research indicate that protein variation cannot interrupt platelet activities. According to Ijiomaet al. (2015) and Van der Bom et al. (2009) fall in platelets count has been associated with high values of bleeding and clotting times with bleeding problems as consequences. Low numbers of circulating platelets as well as platelet dysfunction increase the risk of bleeding (Van der Bom et al., 2009). In animal with myeloproliferative disorders such as essential thrombocythemia, high levels of platelets may be associated with thrombotic and, to a lesser extent, with hemorrhagic complications, mostly at platelet counts exceeding normal range.

Table IV shows the serum parameters of broiler starter fed varied levels of protein at starter phase. Except serum proteins and cholesterol other serum parameters were not affected by varied dietary protein levels. Globulin was steady at lower and recommended levels but the value increased significantly at higher dietary protein level above recommendation $(4.38 \mathrm{~g} / \mathrm{dL})$. Also serum total protein increases with increase in the dietary protein levels and diet with $26 \% \mathrm{CP}$ recorded the highest value $(5.82 \mathrm{~g} / \mathrm{dL})$. Serum cholesterol values were significantly higher at lower protein level unlike serum protein.

Increase in serum total protein with increase in the dietary protein levels (table 4), although serum creatinine was not affected establishes that serum total protein is sensitive to dietary protein variation than creatinine. This agreed with the report of Awosanya et al. (2000), which reported that blood protein and creatinine levels were dependent on the quality of dietary protein. Birds on lower crude protein diet had the highest blood monocytes level $(3.56 \%)$ compare to other treatments, its means irrespective of the protein levels bird were still able to produce sufficient monocytes. It has been established earlier that excessive consumption of protein decreased the availability of protein (Jeong et al., 2010) and increased the excretion of the nitrogen as urea form (Han et al., 2001). Provision of insufficient nutrients limits the potential growth and production of animal, while feeding of excessive nutrients reduces the economic profitability and causes environment pollution (Jongbloed and Lenis, 1992 andPaik, 1996).

Increase of globulin and decrease in albumin are tied to an improved immune system function on broiler (Bovera et al. 2015, 2016) and can positively affecting the health status of birds. Aspartate aminotransferase (AST) and alanine aminotransferase are enzymes released into the blood when certain organs or tissues, particularly the liver (disruption of hepatic cell as a result of necrosis) and heart are injured or damaged. AST and ALT were not affected as a result of varied dietary levels of protein, aspartate aminotransferase (AST) test is not liver specific, and measuring it alone is not

Page 108 
sufficient for liver functionality. Therefore the result of this study indicates that the reduction of protein level up to $20 \% \mathrm{CP}$ did not affect liver and heart functionality.

Table V shows the gut histomorphometric characteristics of broiler fed varied protein level (starter). Except inter villus and crypt depth all the gut histomorphometric characterizes measured were significantly affected by the protein levels. Different parts response significantly different to dietary treatments. Lower protein did not significantly affecting the crypt depth of the broiler chickens except when compared with the day-old record. Twenty percent protein level had the widest surface area.

Histomophometric analysis (table 5) was discovered to be the main parameters when study about gastrointestinal pathophysiology (Gulbinowicz et al., 2004). Twenty percent protein level had the widest surface area, this may be because the birds were able to improve the absorptive surface area to maximize the limited available protein in the diet. This might be a complementary atrophy, to enable the animal ability to obtain the needed nutrient. It seems to be a complexrelationship between small intestine and nutritional factors. According to Caruso et al. (2012) and Thomson et al. (1996), nutrients may directly cause changes or adaptations in the intestinal mucosa. Since all the absorptive and also a part of the digestive capacity of the small intestine occur around and near villi and crypts (Kitt et al., 2001). Similarity between the crypt depths is an indication of sufficient transportation of enterocytes to the tip of the villi. It was reported by Thomson and Keelan, (1986) that various substances and also different physiological or pathological conditions may change the proliferation rate of enterocytes in the crypt and affect their migration rate to the top of the villi.

Table II. Apparent Nutrient Digestibility of Broiler starterFed Varied Levels of Protein

\begin{tabular}{llllll}
\hline $\begin{array}{l}\text { Parameters } \\
(\%)\end{array}$ & $\mathbf{2 0 \%} \mathbf{C P}$ & $\mathbf{2 3 \%} \mathbf{C P}$ & $\mathbf{2 6 \% C P}$ & SEM & SD \pm \\
\hline $\begin{array}{l}\text { Crude } \\
\text { protein }\end{array}$ & $41.26^{\mathrm{c}}$ & $76.21^{\mathrm{a}}$ & $54.26^{\mathrm{b}}$ & 3.02 & 15.73 \\
$\begin{array}{l}\text { Ether } \\
\text { Extract }\end{array}$ & 84.21 & 83.06 & 82.90 & 0.59 & 0.06 \\
Crude Fibre & 25.65 & 35.40 & 33.22 & 2.11 & 10.94 \\
& & & & & \\
Ash & $50.42^{\mathrm{b}}$ & $63.79^{\mathrm{a}}$ & $64.19^{\mathrm{b}}$ & 1.61 & 8.40 \\
& & & & & \\
Dry matter & 69.96 & 73.89 & 71.71 & 0.98 & 5.10 \\
& & & & & \\
NFE & 77.63 & 75.87 & 74.79 & 0.72 & 3.76 \\
\hline
\end{tabular}

a,b,c connote means in the same row with dissimilar superscripts are significant $(\mathrm{p}<0.05) . \mathrm{CP}=$ Crude protein, $\mathrm{SEM}=$ standard error of mean, $\mathrm{SD}=$ standard deviation, $\mathrm{NFE}=$ Nitrogen free extract
Table III. Haematology and serum parameters of the broiler starterfed varied levels of protein

\begin{tabular}{|c|c|c|c|c|c|}
\hline Parameters & $20 \% \mathrm{CP}$ & $23 \% \mathrm{CP}$ & $26 \% \mathrm{CP}$ & SEM & SD \pm \\
\hline $\mathrm{PCV}(\%)$ & $26.67^{a}$ & $22.22^{\mathrm{b}}$ & $20.56^{\mathrm{b}}$ & 0.50 & 3.68 \\
\hline $\mathrm{Hb}(\mathrm{g} / \mathrm{dL})$ & 8.93 & 8.72 & 9.16 & 0.21 & 1.11 \\
\hline $\mathrm{MCHC}(\%)$ & $43.31^{\mathrm{b}}$ & $46.59^{\mathrm{b}}$ & $54.24^{\mathrm{a}}$ & 1.27 & 9.40 \\
\hline $\operatorname{MCV}\left(\mu^{3}\right)$ & $78.01^{\mathrm{a}}$ & $66.65^{\mathrm{b}}$ & $61.51^{\mathrm{c}}$ & 1.38 & 10.17 \\
\hline $\mathrm{MCH}(\mu \mu \mathrm{g})$ & $33.74^{\mathrm{a}}$ & $30.98^{b}$ & $31.82^{\mathrm{b}}$ & 0.27 & 1.96 \\
\hline $\mathrm{Hb}(\mathrm{g} / \mathrm{dL})$ & $11.52^{\mathrm{a}}$ & $10.33^{\mathrm{b}}$ & $10.62^{b}$ & 0.11 & 0.74 \\
\hline $\begin{array}{l}\mathrm{RBC} \\
\left(\times 10^{6} / \mathrm{L}\right)\end{array}$ & $3.42^{\mathrm{a}}$ & $3.33^{\mathrm{b}}$ & $3.34^{\mathrm{b}}$ & 0.01 & 0.07 \\
\hline $\mathrm{WBC}\left(\mathrm{x} 10^{3 /} \mathrm{L}\right)$ & $8.04^{\mathrm{c}}$ & $11.04^{\mathrm{b}}$ & $13.95^{\mathrm{a}}$ & 0.43 & 3.16 \\
\hline $\begin{array}{l}\text { Lymphocytes } \\
(\%)\end{array}$ & 63.89 & 64.00 & 64.00 & 0.02 & 0.19 \\
\hline $\begin{array}{l}\text { Heterophils } \\
(\%)\end{array}$ & 26.77 & 24.33 & 26.56 & 0.23 & 38.49 \\
\hline $\begin{array}{l}\text { Monocytes } \\
(\%)\end{array}$ & $3.56^{\mathrm{a}}$ & $2.79^{b}$ & $2.89^{\mathrm{b}}$ & 0.13 & 0.94 \\
\hline $\begin{array}{l}\text { Eosinophils } \\
(\%)\end{array}$ & $3.33^{\mathrm{b}}$ & $5.33^{\mathrm{a}}$ & $2.22^{c}$ & 0.24 & 1.78 \\
\hline $\begin{array}{l}\text { Basophils } \\
(\%)\end{array}$ & 0.33 & 0.67 & 0.44 & 0.07 & 0.05 \\
\hline $\begin{array}{l}\text { Platelet } \\
\left(\mathrm{x} 10^{4} / \mathrm{L}\right)\end{array}$ & 13.32 & 14.32 & 13.69 & 2.47 & 18.14 \\
\hline
\end{tabular}

a,b,c : connote means in the same row with dissimilar superscripts are significant $(\mathrm{p}<0.05) . \mathrm{CP}=$ Crude protein, $\mathrm{SEM}=$ standard error of mean, $\mathrm{SD}=$ standard deviation

Table IV: Serum parameters of the broiler fed varied levels of protein (Starter phase)

\section{Parameters $20 \% \mathrm{CP} \quad 23 \% \mathrm{CP} \quad 26 \% \mathrm{CP}$ SEM SD \pm}

\begin{tabular}{llllll}
\hline AST (IU/L) & 159.54 & 157.25 & 160.23 & 3.04 & 22.33 \\
& & & & & \\
ALT (IU/L) & 2.99 & 2.92 & 3.00 & 0.09 & 0.69 \\
$\begin{array}{l}\text { Albumin } \\
\text { (g/dL) }\end{array}$ & 1.47 & 1.35 & 1.26 & 0.03 & 0.24 \\
$\begin{array}{l}\text { Globulin } \\
\text { (g/dL) }\end{array}$ & $2.83^{\mathrm{b}}$ & $2.83^{\mathrm{b}}$ & $4.38^{\mathrm{a}}$ & 0.16 & 1.19 \\
$\begin{array}{l}\text { Total } \\
\text { protein } \\
\text { (g/dL) }\end{array}$ & $4.31^{\mathrm{b}}$ & $4.42^{\mathrm{b}}$ & $5.82^{\mathrm{a}}$ & 0.16 & 1.19 \\
$\begin{array}{l}\text { Creatinine } \\
\text { (mg/dL) }\end{array}$ & 1.85 & 2.89 & 1.58 & 0.19 & 1.44 \\
$\begin{array}{l}\text { Cholesterol } \\
\text { (mg/dL) }\end{array}$ & $129.60^{\mathrm{a}}$ & $134.46^{\mathrm{a}}$ & $81.78^{\mathrm{b}}$ & 4.59 & 33.76 \\
\hline & & & & & \\
\hline
\end{tabular}

a,b: connote means in the same row with dissimilar superscripts are significant $(\mathrm{p}<0.05) . \mathrm{CP}=$ Crude protein, SEM $=$ standard error of mean, AST $=$ Aspartate transaminase, $\mathrm{ALT}=$ Alanine transaminase 
Available at https://jscer.org

Table V. Gut Histomorphometric Characteristics of Broiler fed Varied Protein Level (Starter)

\begin{tabular}{|c|c|c|c|c|c|c|}
\hline Parameters & $20 \% \mathrm{CP}$ & $23 \% \mathrm{CP}$ & $26 \% \mathrm{CP}$ & Day-old & $\begin{array}{l}\text { SE } \\
\mathbf{M} \\
\end{array}$ & SD \pm \\
\hline $\begin{array}{l}\text { Villus Height } \\
(\mu \mathrm{m})\end{array}$ & $203.58^{\mathrm{a}}$ & $151.92^{\mathrm{b}}$ & $190.74^{\mathrm{a}}$ & $35.43^{\mathrm{c}}$ & $\begin{array}{c}9.0 \\
1\end{array}$ & 69.86 \\
\hline $\begin{array}{l}\text { Villus width } \\
\quad(\mu \mathrm{m})\end{array}$ & $51.476^{\mathrm{a}}$ & $51.49^{\mathrm{a}}$ & $47.47^{\mathrm{a}}$ & $6.06^{\mathrm{b}}$ & $\begin{array}{c}2.5 \\
7\end{array}$ & 19.97 \\
\hline $\begin{array}{l}\text { Crypt Depth } \\
(\mu \mathrm{m})\end{array}$ & $38.32^{\mathrm{a}}$ & $40.43^{a}$ & $38.40^{\mathrm{a}}$ & $7.16^{\mathrm{b}}$ & $\begin{array}{c}1.8 \\
9\end{array}$ & 14.67 \\
\hline $\mathrm{MT}(\mu \mathrm{m})$ & $19.83^{\mathrm{b}}$ & $18.10^{\mathrm{b}}$ & $26.65^{\mathrm{a}}$ & $12.26^{\mathrm{c}}$ & $\begin{array}{c}1.0 \\
3\end{array}$ & 8.01 \\
\hline $\begin{array}{c}\text { Inter Villus } \\
(\mu \mathrm{m})\end{array}$ & $7.94^{\mathrm{a}}$ & $9.45^{\mathrm{a}}$ & $8.19^{\mathrm{a}}$ & $2.47^{\mathrm{b}}$ & $\begin{array}{c}0.4 \\
5\end{array}$ & 3.50 \\
\hline VH:CD & $4.01^{\mathrm{b}}$ & $2.96^{\mathrm{c}}$ & $3.88^{\mathrm{b}}$ & $5.93^{\mathrm{a}}$ & $\begin{array}{c}0.1 \\
7\end{array}$ & 1.32 \\
\hline $\operatorname{AVSA}(\mu \mathrm{m})$ & $34944.28^{\mathrm{a}}$ & $26731.61^{\mathrm{c}}$ & $31618.08^{b}$ & $699.64^{\mathrm{d}}$ & $\begin{array}{l}87 . \\
56\end{array}$ & 223.41 \\
\hline
\end{tabular}

MT = Muscular Thickness, AVSA= Average Villus Surface Area, SEM = standard error of mean, SD = standard deviation, $\mathrm{BDG}=$ Brewery dry grain, $\mathrm{SSG}=$ Sorghum spent grain.

\section{CONCLUSION}

Serum cholesterol values were significantly higher at lower protein level unlike serum protein whiledifferent gut parts response significantly different to dietary treatments. Conclusion is at early stage broiler growth, diet need to have higher $\mathrm{CP}$ to improve the immunity and health growth of gut.

\section{REFERENCES}

[1] Abdelrahman, M. M. and Aljumaah, R. S. (2014). Dietary protein level and performance of growing Baladi kids. Iranian J. of Veterinary Research, Shiraz University.

[2] Adedokun, S. A. and Adeola, O. (2013). Calcium and phosphorus digestibility: Metabolic limits. The Journal of Applied Poult. Research, Volume 22, Issue 3, Pages 600608.

[3] Adeyemi, O. A., Fasina, O. E. and Balogun, M. O. (2000). Utilization of full fat Jatropha seeds in broiler diet: Effect on haematological parameters and blood chemistry. Proceedings of the 25th Conference of Nigerian Society.

[4] Amber-Jean, N. (2012), United States environmental protection agency: Background.

[5] Awosanya, B., Joseph, J. K., Apata, D. F., Ayoola, M. A. (2000). Performance, blood chemistry and carcass quality attributes of rabbits fed raw and processed Puereria seed meal. Tropical J. of Animal Sci. 7, 89-96.

[6] Bovera, F., Loponte, R., Marono, S., Piccolo, G., Parisi, G., Iaconisi, V., Gasco, L. and Nizza, A. (2016). Use of Tenebrio molitor larvae meal as protein source in broiler diet: effect on growth performance, nutrient digestibility, and carcass and meat traits. J. Anim Sci. 94:639-647.
[7] Bovera, F., Piccolo, G., Gasco, L., Marono, S., Loponte, R., Vassalotti, G., Mastellone, V., Lombardi, P., Attia, Y.A. and Nizza, A. (2015). Yellow mealworm larvae (Tenebrio molitor, L.) as a possible alternative to soybean meal in broiler diets. Br Poult Sci. 56:569-575.

[8] Carlomagno, M. A., Alito, A. E., Rife, S. U. and Glmeno, A. L. (1980). B-cell immune response during total protein deprivation. Acta Physiol. Lat. Am., 30: 187-192.

[9] Caruso, M., Demonte, A. and Neves, V. A. (2012). Histomorphometric study of role of lactoferrin in atrophy of the intestinal mucosa of rats. Health, 4: 1362-1370.

[10] Chineke, C.A., Ologun, A.G. and Ikeobi, C.O.N. (2006).Haematological parameters in rabbit breeds and crosses in humid tropics. Pakistan journal of biological sciences, 9(11), 2102-2106.

[11] Egbunike, G. N., Agiang, E. A., Owosibo, A. O. and Fafute, A.A. (2009). Effect of protein on performance and haematology of broiler fed cassava peel based diets. Archirus De Zeotecnia, 58: 224-656.

[12] Gracia MI, Lázaro R, Latorre MA, Medel P, Araníbar MJ,Jiménez-Moreno E, Mateos GG (2009). Influence of enzymesupplementation of diets and cooking-flaking of maize on digestive traits and growth performance of broilers from 1 to 21 days of age. Anim. Feed Sci. Technol. 150: 303-315.

[13] Gulbinowicz, M., Berdel, B., Wójcik, S., Dziewiatkowski, J., Oikarinen, S., Mutanen, M., Kosma, V. M., Mykkänen, H. and Morys, J. (2004). Morphometric analysis of the small intestine in wild type mice C57BL/6L- a developmental study. Folia Morphol (Warsz), 63: 423-30.

[14] Hu ZH, Guo YM (2006). Effects of dietary sodium butyratesupplementation on the intestinal morphological structure,absorptive function and gut flora in chickens. Anim. Feed Sci. Technol. 132: 240-249. 


\section{Gut Histomorphometric And Blood Profile Of Broiler Chicks Fed Varied Levels Of Protein}

Available at https://jscer.org

[15] Huwaida, E.E. M., Ali, O.H.A., Mohamed, E. A. A. and Yousif, I. A. (2013). Effect of season and dietary protein level on immune response of three exotic broiler strains in Sudan. Online J. Anim. Feed Res.,3(1): 31-35.

[16] Ijioma, S. N., Nwankwo, A.A and Nwosu, C. O. (2015). Comparative acute toxicity and hypoglycaemic studies of five Nigerian indigenous medicinal plants namely: Telfairia occidentalis, Moringa oleifera, Acalyphawilkesiana, Pausinystaliayohimbe and Loranthusmicranthus in experimentally induced hyperglycaemic rats. J. of Biotechnology, Agriculture and Environmental Technology Research. 1(2): 1-16.

[17] Isaac, L.J., Abah, G., Akpan, B. and Ekaette, I.U. (2013).Haematological properties of different breeds and sexes of rabbits. In: proceedings of the 18th annual conference of animal science association of Nigeria. 24-24.

[18] Jeong, T. S., Heo, P. S., Lee, G. Y., Kim, D. H., Ju, W. S.and Kim, Y. Y. (2010). The influence of phase feeding methods on growth performance, meat quality, and production cost in growing-finishing pigs. J. of Animal Sci. and Technology; 52:29-36.

[19] Jongbloed, A. W. and Lenis, N. (1992). Alteration of nutrition as a means to reduce environmental pollution by pigs. Livestock Prod Sci. 31:75-94.

[20] Kitt, S. J., Miller, P. S. and Lewis, A. J. (2001). Factors affecting small intestine development in weanling pigs. Nebraska Swine Report, 33-35.

[21] Lohakare, J. D., Pattanaik, A. K. and Khan, S. A. (2006). Effect of Dietary Protein Levels on the Performance, Nutrient Balances, Metabolic Profile and Thyroid Hormones of Crossbred Calves. Asian-Aust. J. Anim. Sci. Vol. 19, No. 11: $1588-1596$.

[22] Onderci M, Sahin N, Cikim G, Aydin A, Ozercan I, Ozkose E,Ekinci S, Hayirli A, Sahin K (2008). B-Glucanaseproducing bacterialculture improves performance and nutrient utilization and alters gutmorphology of broilers fed a barleybased diet. Anim. Feed Sci. Technol. 146: 87-97.

[23] Oyawoye, B. M. and Ogunkunle, H.N. (2004). Biochemical and haematological reference values in normal experimental animals, New York: Masson. 212-218.

[24] Paik, I. K., Blair, R. and Jacob, J. (1996). Strategies to reduce environmental pollution from animal manure: Principles and nutritional management. A review. Asian-Aus. J Anim Sci.; 9:615-35.

[25] Poultry World (2016). Understanding protein requirements. Retrieved on January 15, 2020 at https://www.poultryworld.net/nutrition/Articles/2016.

[26] Shittu, M. D., Kehinde , O. A., Longe, O. G. and Ewuola, A. O. (2017). Heamatological and serum chemistry of broilers fed differently processed sorghum spent grain. International Journal of Nutrition and Agriculture Research. 4(1), 2017, 4757.

[27] Soetan, K.O., Akinrinde, A.S, and Ajibade, T.O. (2013). Preliminary studies on the haematological parameters of cockerels fed raw and processed guinea corn (sorghumbicolour): In: proceeding of 38th annual conference of Nigerian society for animal production. 49-52.

[28] Thomson, A. B. R. and Keelan, M. (1986). The development of the small intestine. Can J PhysiolPharmacol, 64: 13-29. doi:10.1139/y86-003.

[29] Thomson, A. B. R., Keelan, M. and Wild, G. E. (1996). Nutrients and intestinal adaptation. Clin Invest Med, 19: 331345 .

[30] Tom, K. (2002). U.S. Broiler Industry Structure. National Agriculture Statistics Service, Agricultural Statistics Board, U.S Department of Agriculture.

[31] Van der Bom, J. G., Heckbert, S. R., Lumley, T., Holmes, C. E., Cushman, M., Folsom, A. R., Rosendaal, F. R. and Psaty, B. M. (2009). Platelet count and the risk for thrombosis and death in the elderly. J.ThrombHaemost. 7(3):399-405.

[32] Youssef, A. A., Fulvia, B., Abd-El-Hamid, E. A., Abd-Elrazk, E. T., Mohammed, A. A.., Antonino, N. and Raesa, M. E. (2017). Effect of dietary protein concentrations, amino acids and conjugated linoleic acid supplementations on productive performance and lipid metabolism of broiler chicks, Italian J. of Animal Sci., 16:4, 563-572, DOI: 10.1080/1828051X.2017.1301228. 